\title{
Initial afferent lymphatic vessels controlling outbound leukocyte traffic from skin to lymph nodes
}

\author{
Alvaro Teijeira ${ }^{1}$, Ana Rouzaut ${ }^{1}$ and Ignacio Melero ${ }^{2}$ * \\ ' Centro de Investigación Médica Aplicada, Universidad de Navarra, Pamplona, Spain \\ ${ }^{2}$ Clínica Universitaria, Universidad de Navarra, Pamplona, Spain
}

\section{Edited by:}

Fabrizio Mattei, Istituto Superiore di

Sanità, Italy

Reviewed by:

Sandra Demaria, New York University School of Medicine, USA

Luis De La Cruz-Merino, Hospital

Universitario Virgen Macarena, Spain

*Correspondence:

Ignacio Melero, Clínica Universitaria

Universidad de Navarra, Pamplona

31008, Spain

e-mail:imelero@unav.es
Tissue drains fluid and macromolecules through lymphatic vessels (LVs), which are lined by a specialized endothelium that expresses peculiar differentiation proteins, not found in blood vessels (i.e., LYVE-1, Podoplanin, PROX-1, and VEGFR-3). Lymphatic capillaries are characteristically devoid of a continuous basal membrane and are anchored to the ECM by elastic fibers that act as pulling ropes which open the vessel to avoid edema if tissue volume increases, as it occurs upon inflammation. LVs are also crucial for the transit of $T$ lymphocytes and antigen presenting cells from tissue to draining lymph nodes (LN). Importantly, cell traffic control across lymphatic endothelium is differently regulated under resting and inflammatory conditions. Under steady-state non-inflammatory conditions, leukocytes enter into the lymphatic capillaries through basal membrane gaps (portals). This entrance is integrin-independent and seems to be mainly guided by CCL21 chemokine gradients acting on leukocytes expressing CCR7. In contrast, inflammatory processes in lymphatic capillaries involve a plethora of cytokines, chemokines, leukocyte integrins, and other adhesion molecules. Importantly, under inflammation a role for integrins and their ligands becomes apparent and, as a consequence, the number of leukocytes entering the lymphatic capillaries multiplies several-fold. Enhancing transmigration of dendritic cells en route to $L N$ is conceivably useful for vaccination and cancer immunotherapy, whereas interference with such key mechanisms may ameliorate autoimmunity or excessive inflammation. Recent findings illustrate how, transient cell-to-cell interactions between lymphatic endothelial cells and leukocytes contribute to shape the subsequent behavior of leukocytes and condition the LV for subsequent trans-migratory events.

Keywords: dendritic cell, T cell, lymphatic vessel, migration, inflammation

\section{INTRODUCTION}

The lymphatic vascular system is composed by a one-direction system of conduits interrupted by lymph nodes (LN) that run in parallel to the blood vascular system.

Up to $50 \%$ of the protein that extravasates from blood vessels is reabsorbed by the lymphatic network (1). Besides, lymphatic vessels (LVs) in the gut are also devoted to the transport of absorbed lipids from the diet. One of the main functions of LVs is to conduit immune cells from tissues to the LN. This last function of the LVs constitutes the focus of this review. The cellular mechanisms and molecules involved in leukocyte transit across blood vessels have been studied in more detail and are generally assumed to be similar in the LVs (2). However, it must be stressed that although there are partial parallelisms in cell transit across these two types of vasculature, the diverse structure of the lymphatic capillaries may explain non-overlapping trans-migratory mechanisms. Even more, these peculiarities offer us new opportunities for selective therapeutic intervention to modulate leukocyte transit across the lymphatic capillaries.

The majority of the leukocyte populations that travels via the lymphatics to the $\mathrm{LN}$ are $\mathrm{CD} 4^{+}$lymphocytes, including effector memory and regulatory T cells (3-5). Myeloid cells also use the same conduits $(6,7)$, the majority of them being dendritic cells (DC) $(8,9)$. Myeloid cells are present in the lymph in lower amounts in homeostasis respect to $\mathrm{T}$ lymphocytes but their quantities significantly increase under inflammatory conditions.

Dendritic cells are key elements of the adaptive immunity that patrol peripheral tissues in search of pathogens or damage signals. Their main mission is to recognize and process foreign antigens in peripheral tissues and ferry them to the LN where they are presented to naïve $\mathrm{T}$ cells and then trigger an effective immune response.

In consequence, DC traffic toward LN via LVs has been extensively studied by immunologists in the recent years. Due to their abundance in the skin and its accessibility, DC transit in this tissue in homeostasis and inflammation has been the model used for most of the experimental studies. DCs from the skin include epidermal resident $\mathrm{CD} 206^{+}$Langerhans cells as well as dermal resident DC. Importantly, both cell types migrate at different times to the LN after contacting pathogen [for review Ref. (10)]. DC migration to the LN under steady-state conditions is constant and occurs at modest intensity (11) being instrumental to preserve peripheral tolerance to self-antigens (12-15). In contrast, under inflammation, DC migration toward the LN is significantly 
increased in response to chemotactic signals induced by inflammatory products (16). The amount of DC and specific subpopulation of antigen presenting DC (APC) entering into in the LN from peripheral tissues is important not only to elicit but also to sustain proper adaptive immune responses against pathogens. Therefore, the existence of regulation mechanisms for leukocyte-egress routes from the peripheral tissue is reasonable. Such mechanisms as consequence regulate leukocyte entrance into $\mathrm{LN}$ (16).

\section{LYMPHATIC VESSELS UNDER STEADY-STATE AND PRO-INFLAMMATORY CONDITIONS}

Leukocyte entry into the LVs is determined by the peculiar morphological features of these vessels: they are endowed with an intermittent basement membrane and their intercellular junctions are dispersed in button-like structures that leave small flaps of loose overlapping membrane extensions between individual LEC (17). Further, the LVs are attached to the extracellular matrix by anchoring fibers $(18,19)$ that stretch when tissue volume increases and lead to the opening the inter-endothelial flaps (19). It has been firmly established how under steady-state conditions DCs are able to penetrate into LVs via the preexisting pores (portals) of their basal membrane and subsequently migrate into LVs through inter-endothelial cell openings. This migration occurs in a process guided by chemokine gradients and mediated by contractions of the actin cytoskeleton, but is independent from integrin engagement, as it was shown in experiments performed in mice whose traceable DC are devoid of all integrins as bona fide pan-integrin knock-out DC mice (20).

It has recently been reported that during chronic inflammation or extensive lymphangiogenesis, there exists a transformation of the dispersed button-like adhesive structures of the mature lymphatic capillaries into ones more restrictive for cell transit featuring zipper-like contact adhesions similar to those present in collecting LVs and in blood capillaries. Importantly, this transformation is reversible and dependent on the activation of the glucocorticoid receptor by its phosphorylation (21). In fact, additional findings supported these observations. For example, it was reported how inflammatory cytokines (22) and pathogen-associated patterns (23) can promote VEGF-C production by the stromal cells and induce the formation of new LVs (lymphangiogenesis). In these models, inhibition of signaling across its receptor VEGFR3 impaired the resolution of inflammation while its activation attenuated edema and induced the sprouting of new LVs (24-27). Besides, it has been extensively reported how increments in LVs facilitate the local resolution of the immune and inflammatory responses by augmenting DC transit across their boundaries (27, 28).

In line with this experimental evidence, it has been demonstrated how inflammatory mediators such as $\mathrm{TNF} \alpha$ induce the up-regulation of integrin ligands on LVs surface such as VCAM and ICAM-1 and induce changes in the secretion of chemotactic cytokines both in in vitro and in vivo settings (29, 30). CCL21 is the main cytokine that drives DC migration to the LVs and its expression by LVs is strongly up-regulated upon exposure to pro-inflammatory cytokines such as TNF $\alpha$ (31). Nevertheless, other cytokines such as IFN $\gamma$ limit LV proliferation (32) suggesting that transit of DCs across the lymphatic boundaries seems to be a phenomenon highly controlled by inflammatory mediators, although the precise molecules at work in each situation seem to vary. Indeed, previous reports from Vigl et al. showed how different models of inflammation (i.e., contact hypersensibility, CHS induction, or CFA injection) lead to diverse changes in LEC phenotypes in a stimulus-dependent manner (30). Other reports have demonstrated that the characteristic increment in transmural lymph flow that accompanies inflammation also results in greater CCL21 cytokine expression and leukocyte transmigration across LEC (33). Besides, to further support the role of this cytokine in DC migration Tal and co-workers have recently demonstrated by in vivo time-lapse microscopy that DC not only ingress the initial lymphatics through basal membrane deprived portals located in close proximity to CCL21 depots, but once inside the vessel these leukocytes crawl directionally on the luminal-side of the capillary. To crawl DC advance extending filopodia at their leading edges and retracting uropods formed at their rear end (34). These cells moved in a way that much resembles the inflammation-mediated integrin crawling of leukocytes inside the lumen of blood capillaries before their extravasation into tissues (35).

Peripheral inflammation is also able to promote effects in distant LN. Reports from Kinder and co-workers show how peripheral activated mast cells release micro particles that contain TNF $\alpha$ and other vasoactive mediators that facilitate leukocyte-egress toward the LN and induce the lymphangiogenesis of the lymphatic sinusoids in secondary lymphoid organs $(36,37)$. This new mechanism results in long distance-education of draining $\mathrm{LN}$ for the eventual reception of activated leukocytes $(38,39)$.

In addition to APC and effector T lymphocytes, T cells that infiltrate healthy or inflamed tissues may differentiate into a memory subset that expresses CCR7 and recirculates to LN (40-42). Similarly to DC, the arrival of antigen experienced T lymphocytes to $\mathrm{LN}$ is critical to regulate the intensity of immune responses. It is clear that there is much more detailed information regarding the mechanisms that drive the entrance of leukocytes to tissue to form inflammatory infiltrates than those that govern egress from tissue via afferent LVs. The most actively studied lymphtraveler leukocytes are DCs. However, memory T cell traffic for recirculation is also quite important and its understudied molecular mechanisms deserve much future attention, as is also the case with polymorphonuclear leukocytes (PMN).

Polymorphonuclear leukocytes upon acute inflammation are routed to LN via the lymph $(43,44)$ with potential to ferry antigens and pathogen-associated patterns (45) and regulate antigen presentation at the LN (43). Besides, DCs which have engulfed PMN also migrate via afferent LVs and may deliver PMN associated antigenic material to $\mathrm{LN}$ resident DC (45).

The experimental methodology used so far for the assessment of the interplay between leukocytes and LVs is quite similar to those in use for many years to study cell transit across blood capillaries and are being described next.

\section{CURRENT EXPERIMENTAL MODELS TO STUDY LEUKOCYTE TRANSIT ACROSS LYMPHATIC VESSELS}

Much of our current view on leukocyte transit across different lymphatic vascular beads depends on the experimental setting used. A graphical summary of such approaches is shown in Figure 1. 


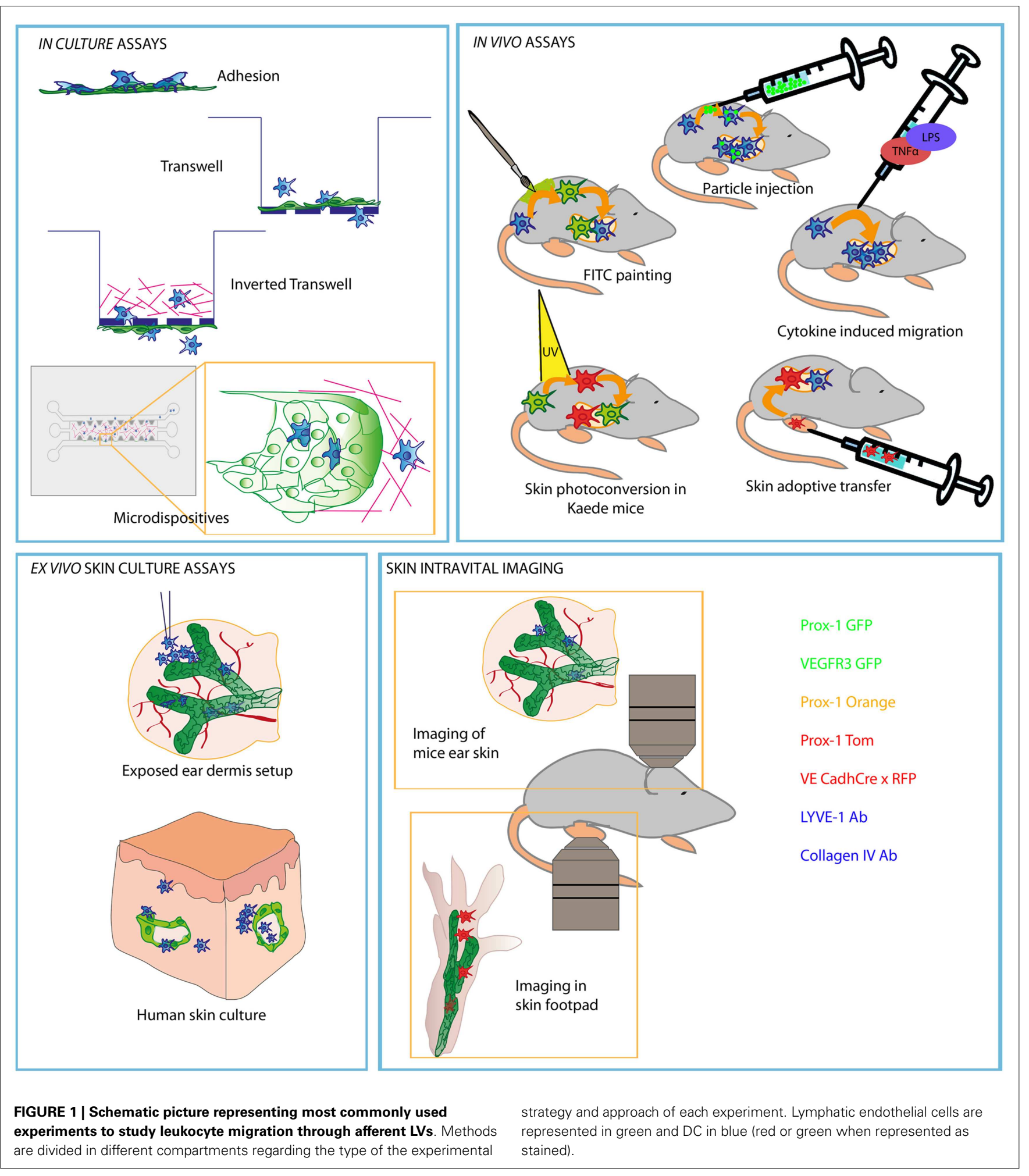

\section{ENDOTHELIAL CELL CULTURES}

Human LECs can be purified based on the expression of specific markers (46) and are also commercially available as primary cells purified from human tissues such as dermis or lung.
In this line, it is worth mentioning that LEC present different biological properties depending on their original tissue niche (47). From them, immortalized mouse LEC cell lines have been derived. The cell line most frequently used was purified from 
transgenic mice strains (SV-LEC) in which the expression of temperature sensitive SV40T antigen immortalized the lymphatic endothelial cells (48). This cell line is grown in special culture media and needs to be kept in culture at $33^{\circ} \mathrm{C}$ to maintain their immortalized status, making their use as routine experimental tool rather cumbersome. Other lymphatic endothelial cell lines derived from murine lymphoangiomas such as MELC cells have also been reported (49). This cell line retains most of the characteristics of primary lymphatic endothelial cells, but do not retain other features such as LYVE-1 expression. Still, they are a valuable source for research on lymphatic endothelial cell function since they can be in vitro propagated and assayed for transcriptional and functional assays. Primary isolated or immortalized lymphatic endothelial cells can also be transfected by liposome-based methodology and more powerful transfection techniques such as nucleofection or retrovirus mediated gene transfer $(50,51)$. Reliable methods to culture primary mouse LECs are not in place at the moment although it would offer definitive advantages.

The in vitro study of leukocyte adhesion to LEC monolayers provides quantitative data and permits experiments with blocking monoclonal antibodies to assess the role of different adhesion molecules $(29,52,53)$ as a preliminary tool to describe cell transit across these vessels. Besides, this set up allows DC imaging on fixed and live specimens of lymphatic endothelial cells $(33,54$, 55). In contrast, one of the mayor limitations of this experimental approach derives from the fact that leukocyte binding to monolayers of LEC adhered to plastic or ECM coated wells ignores the apical to basal polarization of the endothelial cells. Even though a lack of polarization has been reported for these cells in culture (29), in those experiments, DC used the same molecules to adhere to either the apical or the basal face of the endothelium (56). However, more research is needed about the importance of polarity for cell transit across LVs.

A second feasible and reproducible in vitro assay relies on the use of transwell systems in which the endothelial cells are seeded on the bottom of the transmigration filter between chambers. Migratory cells are then added on the upper well of the camber and allowed to cross the endothelium following a chemotactic gradient originated in the bottom well of the dispositive. This methodology also provides the researcher with a quantitative system to assess chemokine-driven active migration across monolayers. By using blocking monoclonal antibodies and decoy receptors the contribution of each of the different receptors can also be tested. An advantage of the use of transwell assays is the possibility to analyze basal to apical migration, but attention should be paid to pore size and the type of ECM proteins used to coat the transmigration membranes between chambers $(33,54)$.

Novel approaches in cell culture have been developed to grow endothelial structures in 3D micro-devices that allow both physicochemical and confocal microscope-based analysis of cell transmigration across endothelial tubules (57-59). These devices have been mainly applied to study tumor cell biology and metastasis but are promising in the context of cell migration across LEC as an attractive system for live imaging of leukocyte-LEC interaction.

\section{EX VIVO ASSAYS}

This experimental approach is based on the isolation and culture in vitro of skin samples obtained from animals or surgery samples, under sterile conditions. It has been used for the study of DCs emigration from tissue (60). This technical approach simulates more accurately the physiological context than the previously mentioned in vitro assays. In this ex vivo set up, the visualization of tissue-resident DC in their way across LVs by confocal microscopy is challenging due to the scarce number of endogenous DC in the tissue sample and their lack of motility once explanted from tissue. Therefore, it is more feasible to directly add in vitro differentiated DC onto the explanted skin samples or inject traceable DC to the animals before sacrifice. Using this methodology leukocyte migration toward LVs has been observed by in situ imaging (61) and quantitative assays in this respect have been reported $(29,62)$. Though offering evident advantages, tissue explants also present some drawbacks because: (i) DC may abandon the tissue using other routes different from LVs; (ii) explanted tissue offers limited viability in culture (3 days, the longest in our hands); (iii) the experiments are performed in the absence of lymph flow.

\section{IN VIVO MODELS}

The main in vivo approximations for the study of DC migration across LVs have been reviewed in depth elsewhere (63). Briefly, current functional assays for the study of leukocyte migration toward the LNs are based largely in two different experimental approaches: the application of different inflammatory stimuli to induce endogenous DC migration, and the adoptive transfer of in vitro differentiated DC. The first type of experiments include FITC painting $(16,64)$, injection of fluorochrome-loaded particles (65), or the application of pro-inflammatory agents to the skin (66). FITC painting allows easy tracing of those leukocytes that have migrated out from skin since they are fluorescent. A pitfall of this methodology is that FITC molecule works as hapten and produces inflammation per se, hence being unsuitable for the investigation of steady-state cell migration. Injection of labeled microparticles is used to follow phagocytic DC populations and presents the advantage of allowing the study of DC migration under steady-state conditions. In addition, since these microparticles can be labeled with different fluorochromes, multiple DC populations can be traced in one single experiment. Direct injection or application of pro-inflammatory agents on the skin makes possible the study of the changes in endogenous DC populations both in the skin and in the draining LN. This approximation is useful to assess differential immunological responses to diverse inflammatory stimuli. However, with this technique it is not possible to directly follow DC migratory events. To overcome this problem, mice engineered to express the photoconvertible fluorescence protein Kaede, which changes from green to red when exposed to violet light have been used in experiments to trace the destiny of different leukocyte populations. In this line, Tomura and co-workers trace skin lymphocytes routed to draining LNs after skin exposure to violet light (5). Again, it is likely that photoconversion might act as an inflammatory stimulus.

More accessible methods are based on the adoptive transfer of pre-stained or genetically tagged DCs or T cells. This approach facilitates the study of the migration of leukocytes obtained from 
different transgenic models, while keeping a wild type background in the receptor mice $(53,67)$. The main limitations of this technique derive from the fact that experiments are usually performed with DC differentiated in culture and not with actual tissue-resident populations. It should be noted that DC are phenotypically diverse and may respond differently to environmental stimuli. Besides, the injection of the cells directly into the tissue may produce minor inflammation and undesired leukocyte activation.

Recently, intravital imaging has become a powerful tool to dissect the biology of leukocyte intravasation into the LVs. This approach captures images of cells as they migrate toward and traverse the lymphatic endothelium in live animals in a non-invasive fashion. For this purpose, increasingly sophisticated two-photon fluorescent microscopy technology leads our progress. Indeed, this methodology has provided crucial in vivo information about DC migration across LVs in steady-state conditions (34, 55). Besides, many mouse models have been developed to visualize LVs by in vivo microscopy based on the selective expression of fluorescent proteins under the regulation of different promoters $(55,68-72)$ or by the use of fluorescence-labeled antibodies $(34,73)$. Non-invasiveness and performance of the experiments in intact animals allows continuous lymph flow and makes this approach very suitable, since the main shortcomings from the previously explained methodologies are overcome. Yet, there are limitations to in vivo microscopy such as paucity of relevant transgenic animals expressing fluorescent protein under suitable promoters to study leukocyte entrance into lymphatics, and the fact that experimentation with human cells in this setting is impossible.

\section{ADHESION MOLECULES, CYTOKINES, AND CHEMOKINES THAT CONTROL LEUKOCYTE TRANSIT INTO LYMPHATIC VESSELS CHEMOKINES INVOLVED IN LEUKOCYTE TRAFFICKING INTO LVS}

Dendritic cells and T cells follow chemotactic gradients that lead them toward the LVs and facilitate their transmigration and crawl on the luminal-side of the lymphatic capillaries until they reach the wider collector vessels from where lymph flow drifts them toward LNs (34). The role of the chemokine receptors and adhesive molecules and the models in which they have been investigated are summarized in Table 1.

The main chemokine-chemokine receptor system that controls leukocyte migration to LNs is CCL21/CCL19-CCR7 axis. The CCR7 chemokine receptor is expressed on DC under steadystate conditions but is strongly up-regulated upon maturation (74). This chemokine receptor has been described as instrumental for DC migration to LNs in experiments using adoptively transferred or autochthonous dermal DCs both under inflammation and steady-state conditions $(11,67)$. The same function applies for T lymphocyte $(40,41)$ and neutrophil (44) migration into the LVs.

The ligands of the CCR7 receptor are CCL21 and CCL19 chemokines. CCL21 is mainly produced by LEC in peripheral tissues and it is adsorbed onto heparan sulfate residues present in the ECM through its positive charged C-terminal end $(75,76)$. A single aminoacid variant of CCL21 (CCL21-Ser) is expressed by high endothelial venules (HEVs) and fibroblast reticular cells (FRCs) present in secondary lymphoid organs to guide T lymphocytes and DC into the T zone. CCL21 is better sensed by CCR7 ${ }^{+}$ leukocytes when it is adsorbed onto surfaces and enhances cell mobility by a phenomenon called haptotaxis $(77,78)$. Besides, CCL21 can be proteolyzed by activated DC generating soluble gradients that attract DC by chemotaxis as well. Following inflammation, CCL21 biosynthesis by LEC is up-regulated and accounts for the enhanced leukocyte chemotaxis toward the LVs observed in animal models $(30,31,79)$. In fact, in vivo confocalbased evidences show how DCs directly interact with the CCL21 patches deposited on the areas where lymphatic endothelium is deprived of basal membrane (34). From these points of entry DC subsequently crawl inside LVs (Figure 2). Interestingly, it has been demonstrated how CCL21 is needed for integrin dependent transmigration across LEC and promotes DC integrin activation through the erection from their low affinity bent conformation to the extended high affinity form $(31,80,81)$. As expected, DCs lacking CCR7 do not dock successfully to CCL21 depots on LVs.

CCL19/MIP3 $\beta$ is a soluble CC chemokine abundantly expressed in the thymus and in FRC from the LNs but it is not expressed by LVs. Contrarily to what happens with CCL21, CCL19 lacks a negatively charged C-terminus and therefore does not bind to the glycosaminoglycans present in the ECM. In tissue, CCL19 is mainly produced by activated DCs and diffuses as soluble gradients for subsequent DC, and maybe T cells, to follow behind (82). All in all, the conjunctive activity of CCL21 and CCL19 cytokines, accounts for all CCR7-dependent DC migration toward LVs (77). Still, the specific role of each one of these chemokines in DC migration is still under discussion, although the majority of the experimental evidence shows that CCL21 is the predominant chemokine in the guidance of DC migration and intravasation $(34,78)$.

An interesting and unresolved paradox is that while CCR7 expression is the trademark of central memory $\mathrm{T}$ lymphocytes $(83,84)$ it is not expressed by $\mathrm{T}$ effector memory counterparts. The afferent lymph contains abundant $\mathrm{CD} 4^{+}$and $\mathrm{CD} 8^{+} \mathrm{T}$ cells which are CCR7 ${ }^{+}$as well $(40,84)$. It is then conceivably that some of the $\mathrm{T}$ cells infiltrating peripheral tissue regain CCR7 expression to enter afferent LVs in a CCR7-dependent fashion $(40,41)$. It has been reported that egress of $\mathrm{CD}^{+} \mathrm{T}$ cells is more efficient than $\mathrm{CD}^{+} \mathrm{T}$ cells or B cells (41) but the underlying mechanism has not been uncovered yet. To complicate things further, it has been described how under chronic inflammation dependency for outmigration on CCR7 is not total and other mechanisms are involved including random migration (42).

CXCR4 is another member of the chemokine receptor family up-regulated on DC upon maturation (74). The implications of its cognate chemokine CXCL12 in DC migration have been demonstrated in vivo. It has been reported that hypoxia and inflammation drives up-regulation of this chemokine in LEC (30). CXCR4 inhibition impairs DC migration in response to FITC and CHS (85). Interestingly, CXCL12 has been proposed to enhance survival and promote the maturation of DC (86).

The lipid Sphingosine-1-Phosphate (S1P) and its receptors (87) have been extensively studied in lymphocyte egress from the LN 
Table 1 | Summarizing table of the main molecular players described in Leukocyte traffic through LVs

\begin{tabular}{|c|c|c|c|c|}
\hline $\begin{array}{l}\text { LEC receptor/ } \\
\text { ligand }\end{array}$ & $\begin{array}{l}\text { Leukocyte } \\
\text { receptor/ligand }\end{array}$ & Experimental model & Key observations & Reference \\
\hline CCL21 & CCR7 & $\begin{array}{l}\text { DC and T adoptive transfer of CCR7-l-, LN } \\
\text { analysis on } \mathrm{CCR}^{-/-} \text {mice, IVM of footpad }\end{array}$ & $\begin{array}{l}\text { DC, lymphocytes, and neutrophils fail to migrate } \\
\text { into LVs to LNs both under steady-state and } \\
\text { inflammatory conditions }\end{array}$ & $\begin{array}{l}(11,34,40 \\
41,67,78)\end{array}$ \\
\hline CXCL12 & CXCR4 & $\begin{array}{l}\text { FITC painting in the presence of a chemical } \\
\text { inhibitor, transwell assays, inflammation models }\end{array}$ & $\begin{array}{l}\text { Impaired DC migration to LN when treated with } \\
\text { inhibitor. Induces transmigration across LEC in } \\
\text { transwell assays. Impaired CHS response when } \\
\text { inhibited }\end{array}$ & $(62,85)$ \\
\hline S1P & S1PR1-5 & $\begin{array}{l}\text { FITC painting in the presence of chemical } \\
\text { inhibitor FTY720, DC analysis in LN under } \\
\text { inflammation and in the presence of inhibitor, } \\
\text { adoptive skin transfer of T lymphocytes, and } \\
\text { whole mount immunofluorescence after ear } \\
\text { injection in FTY720 treated cells }\end{array}$ & $\begin{array}{l}\text { Impaired DC and T cell migration from skin to } \\
\text { LNs. Induced by inhibitor. Impaired in vitro } \\
\text { trans-endothelial migration in LVs. Induces } \\
\text { transmigration across LEC in transwell assays }\end{array}$ & $\begin{array}{l}(54,91,92, \\
97)\end{array}$ \\
\hline D6 & $\begin{array}{l}\text { Inflammatory } \\
\text { chemokines }\end{array}$ & $\begin{array}{l}\text { Immunofluorescence of skin LVs and LNs and } \\
\text { study of LN DC populations after TPA induced } \\
\text { inflammation in D6 }{ }^{-/-} \text {mice }\end{array}$ & $\begin{array}{l}\text { Accumulated inflammatory cells blocking LV } \\
\text { function and other DC migration in } \mathrm{D6}^{-1-} \text { mice }\end{array}$ & $(105)$ \\
\hline CX3CL1 & CX3CR1 & $\begin{array}{l}\text { FITC painting in CHS preinflamed skin in the } \\
\text { presence of CX3CL1 Abs, adoptive transfer of } \\
\text { CX3CL1-/- BMDCs, transwell assays }\end{array}$ & $\begin{array}{l}\text { DC migration to LN is delayed. Impaired in vitro } \\
\text { migration when the chemokine or its secretion } \\
\text { is blocked. Effects only observed under } \\
\text { inflammation }\end{array}$ & (99) \\
\hline PECAM & PECAM & $\begin{array}{l}\text { Transwell assays, ex vivo human skin culture in } \\
\text { the presence of blocking Ab, } \\
\text { immunofluorescence, and DC count inside LVs }\end{array}$ & $\begin{array}{l}\text { Impaired trans-endothelial migration and } \\
\text { intravasation in human skin explants, evidence } \\
\text { provided only in human }\end{array}$ & (62) \\
\hline VCAM & VLA-4 & $\begin{array}{l}\text { BMDC adoptive transfer in the presence of } \\
\text { blocking Abs, transwell assays }\end{array}$ & $\begin{array}{l}\text { LN impaired DC migration under inflammation } \\
\text { and impaired in vitro trans-endothelial migration }\end{array}$ & (29) \\
\hline CD99 & PILR & $\begin{array}{l}\text { Transwell assays, ex vivo human skin culture in } \\
\text { the presence of blocking Ab, } \\
\text { immunofluorescence, and DC count inside LVs }\end{array}$ & $\begin{array}{l}\text { Impaired trans-endothelial migration and } \\
\text { intravasation in human skin explants, evidence } \\
\text { provided only in human }\end{array}$ & (62) \\
\hline L1CAM & L1CAM & $\begin{array}{l}\text { FITC painting assays in mice deficient in L1CAM } \\
\text { under Tie } 2 \text { promoter, transwell, and adhesion } \\
\text { assays }\end{array}$ & $\begin{array}{l}\text { Impaired adhesion, transmigration in human } \\
\text { (moDC) and mice (BMDC), impaired migration } \\
\text { to } L N\end{array}$ & (52) \\
\hline ALCAM & CD6 & $\begin{array}{l}\text { Lung injection of FITC microbeads in } \text { ALCAM }^{-/-} \\
\text {mice }\end{array}$ & Impaired DC arrival to $\mathrm{LNs}$ in $\mathrm{ALCAM}^{-/-}$mice & (119) \\
\hline Podoplanin & CLEC-2 & $\begin{array}{l}\text { FITC painting in } \mathrm{CLEC} 1 \mathrm{~b}^{-/-} \text {mice, adoptive } \\
\text { transfer of } \mathrm{CLEC} 1 \mathrm{~b}^{-/-} \mathrm{DC} \text {, } \\
\text { immunofluorescence of mice ear dermis } \\
\text { cultured with } \mathrm{BMDC}\end{array}$ & $\begin{array}{l}\text { Impaired arrival of DC to } L N \text {, impaired } \\
\text { intravasation, importance for protrusion } \\
\text { formation }\end{array}$ & (123) \\
\hline JAM-A & JAM-A & $\begin{array}{l}\text { CHS response and FITC painting in Jam-A }{ }^{-/-} \\
\text {and adoptive transfer of Jam-A deficient BM } \\
\text { DCs, transwell assays }\end{array}$ & $\begin{array}{l}\text { Jam-A ablation increases DC migration to } \mathrm{LN} \\
\text { and } \mathrm{CHS} \text { responses as well as in vitro TEM }\end{array}$ & (161) \\
\hline
\end{tabular}


Table 1 | Continued

\begin{tabular}{|c|c|c|c|c|}
\hline $\begin{array}{l}\text { LEC receptor/ } \\
\text { ligand }\end{array}$ & $\begin{array}{l}\text { Leukocyte } \\
\text { receptor/ligand }\end{array}$ & Experimental model & Key observations & Reference \\
\hline CLEVER-1 & - & $\begin{array}{l}\text { Adoptive lymphocyte transfer in the presence of } \\
\text { blocking Abs in mice and rabbit }\end{array}$ & Lymph node migration of lymphocytes is blocked & $(127)$ \\
\hline $\begin{array}{l}\text { Mannose } \\
\text { receptor }\end{array}$ & Glycoproteins & $\begin{array}{l}\text { Adoptive lymphocyte transfer in footpad of } \\
\mathrm{MR}^{-/-} \text {mice and IF of LNs }\end{array}$ & $\begin{array}{l}\text { Lymphocyte migration to LN and adhesion to LEC } \\
\text { in LNs is impaired }\end{array}$ & $(130)$ \\
\hline $\begin{array}{l}\text { Semaphorin } \\
3 \mathrm{~A}\end{array}$ & Plexin-A1 & $\begin{array}{l}\text { Adoptive transfer of Plexin-A1-/- BMDCs, or wt } \\
\text { DCs in Sema3A-l- mice, functional studies of T } \\
\text { cell responses upon OVA skin sensitization in } \\
\text { Plexin-A } 1^{-1-} \text { mice. In vitro videomicroscopy }\end{array}$ & $\begin{array}{l}\text { Both, Plexin-A1 and Sema3A absence impairs DC } \\
\text { migration to LNs. Sema3A is able to induce } \\
\text { actomyosin contraction in BMDCs }\end{array}$ & $(125)$ \\
\hline
\end{tabular}

The table includes ligands expressed on both leukocyte and LEC, the evidence provided in leukocyte traffic and the experimental approach performed.

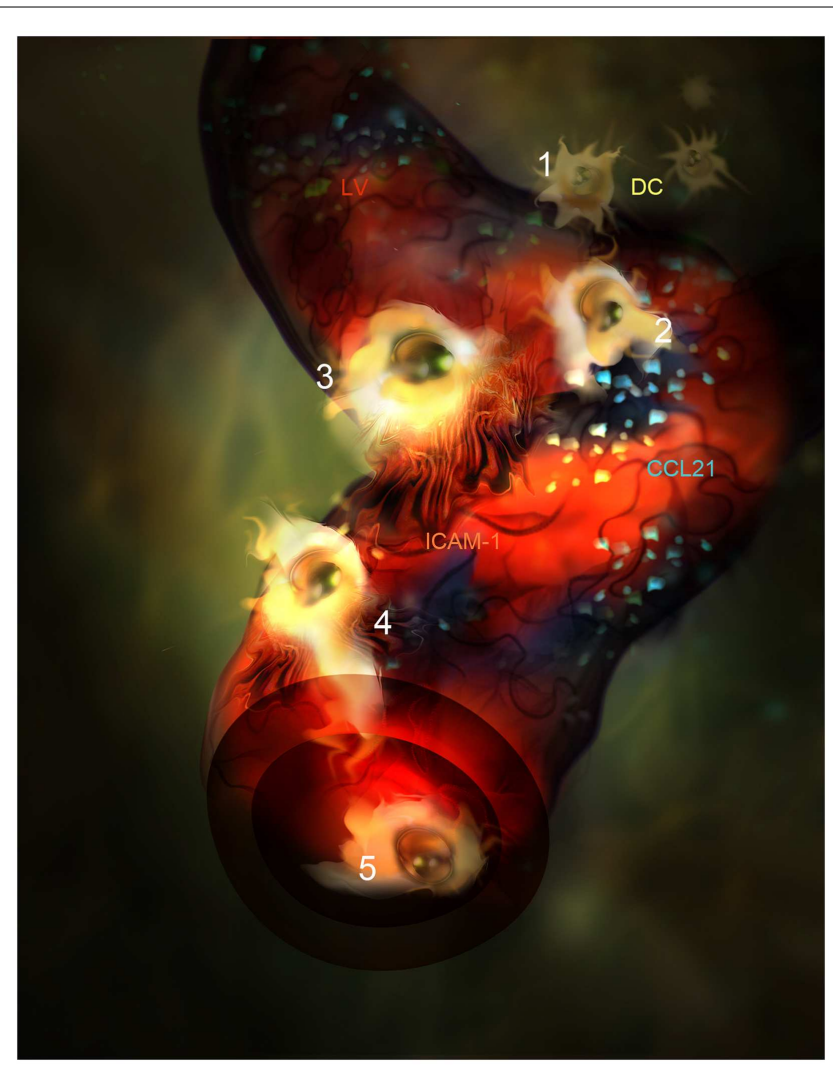

FIGURE 2 | Artistic representation of novel steps in DC migration into LVs under inflammatory conditions. (1) DC (Yellow) are attracted by CCL21 interstitial gradient and other chemokines toward LVs lined by specialized endothelial cells (red). (2) DCs dock to CCL21 (blue) adsorbed as enriched patches prior to adhesion and intravasation. (3) DCs adhere to LEC surface and get entrapped by ICAM-1 enriched microvilli

projections(Orange). (4) DC intravasate in a LV accompanied by ICAM-1 enriched microvilli projections. (5) DC actively crawl inside the LV.

into lymph and blood $(88,89)$. Besides, the LVs had been reported to express Sphingosine Kinases and secrete S1P.

Although S1P expression is dispensable for homeostatic migration of DCs (90), S1P readily augments upon inflammation and presents a leading role in guiding $\mathrm{T}$ lymphocytes into LVs during acute inflammation (54) but is less important for memory/effector T cell egress from tissues during chronic inflammation (42). In fact, a number of reports show how S1P directs the migration of bone marrow-derived mature DC (91), skin DCs (92), or other DC subsets (93). Treatment of DCs with FTY720, a potent S1P analog that induces internalization of S1P receptors (94), block DC migration into LVs and their arrival to LNs (91). In addition, it has been reported how lack of CD69, that sequestrates S1PRs in lymphocytes $(95,96)$, enhances the effects of S1P-driven migration on T cell and DCs (97). Other inflammatory lipids such as $\mathrm{PGD}_{2}$ also sensitize memory $\mathrm{T}$ cells for egress from tissue to $\mathrm{LN}$ in a CCR7-dependent manner (98).

Recently the chemokine CX3CL1/Fractalkine has been involved in DC transit across LVs (99). This cytokine is only expressed upon inflammation and is differently processed in blood and LVs. In blood capillaries CX3CL1 is expressed predominantly as a transmembrane endothelial cytokine with both adhesive and chemoattractanct functions while in lymphatic capillaries it is, almost in its totality, shed from the basolateral surface of the lymphatic capillary and released as soluble chemokine. Importantly CX3CL1 lacks acidic residues and hence diffuses freely through the ECM promoting chemotaxis but not haptotactic migration. In fact, it seems to act as a premier inflammation-driven soluble attractor for tissue-resident DC before CCL21 is deposited on the ECM. In addition, CX3CL1 receptor (CX3CR1) impairment partially inhibits DC migration to LN and concomitant blockade of CCL21 does not show additive effects. The study of the specific mechanisms that this chemokine promotes in an in vivo setting deserves further research.

Another molecule involved in chemokine-driven DC migration is the chemokine decoy receptor D6. This protein is a nonsignaling scavenging receptor $(100,101)$ that binds some inflammatory chemokines but does not bind CCL21 (102, 103). D6 is expressed on LEC surface after being cultured in the presence of inflammatory cytokines such as IL-6 or IFN $\gamma$ (104). In vitro D6 elimination from primary LECs selectively increases the adhesion of immature DCs but not mature DC (104) and mice knockeddown for D6 showed impaired DC migration to LNs by means of macrophage accumulation around LVs (105). Therefore, it seems 
that D6 acts on LVs as scavenger receptor to avoid the adhesion of DC or other leukocytes that fail to express CCR7.

In our group we have been interested in the role of inflammation induced receptors in the modulation of DC transit across LVs. We have studied the participation of CD137/TNFR9/4-1BB, a receptor of the TNFR family receptors in this process. We demonstrated CD137 up-regulation in inflamed LVs. Besides, CD137 cross-linking with an agonistic mAb resulted in the upregulation of VCAM, and increased production of CCL21 and DC accumulation close to LVs (81).

\section{ADHESION MOLECULES INVOLVED IN LEUKOCYTE TRAFFICKING INTO LVS}

To traverse LVs, leukocytes must find the gaps opened in their basal membrane and situate on top of the open endothelial flaps devoid of intercellular junctions. From there, cells must squeeze their cytoplasm by cytoskeletal contraction and nuclear deformation, a process in which Rho associated protein kinases have a said (106). This transit although originally described to occur in an integrin-independent manner, is now seen as a dynamic process modulated by context dependent-factors. In fact, the participation of adhesion molecules as expressed on LVs during leukocyte transit, particularly those belonging to the family of integrin receptors, is a field under intensive investigation (Table 1). Besides, a number of receptors not belonging to CAMs family have recently been described in this process such as podoplanin, CLEVER-1, Plexin $\mathrm{A}$, and CD137.

The role of ICAM-1 and VCAM in leukocyte intravasation into LVs has been controversial. Seminal studies showed a role of ICAM- 1 and $\beta 2$ integrins in DC migration toward LNs $(107,108)$. However, as mentioned above Lämmerman and colleagues showed the entrance of DCs genetically devoid of every known integrin into LVs in ex vivo explanted non-inflammed mouse ears (61). In contrast, TNF $\alpha$, or TLR agonists induce the integrin ligands ICAM-1 and VCAM expression on $\operatorname{LEC~}(29,30,109)$. These same ligands are expressed at low levels in non-inflamed LVs. Besides, blocking these CAMs or their integrin ligands inhibited the migration of DC to LNs under inflammation as well as in vitro assessed trans-endothelial migration (TEM) $(29,31,53)$. These apparently opposing results are reconciled in light of the differential distribution of the adhesive structure under inflammatory conditions: McDonald and co-workers showed the transformation of buttonlike junction structures into zipper-like junctions after chronic inflammation of lung lymphatic capillaries. Thus, it seems reasonable to speculate that under these circumstances the LVs become less permeable to cell transit as a mean to regulate leukocyte transit during the resolution of tissue inflammation. In this regard, we have recently observed that ICAM-1 and VCAM integrin ligands usher DC crawling over LEC and TEM by forming microvilli like projections similar to those previously described in vascular endothelium $(56,110,111)$. Such structures were only observed under inflammatory conditions and were not formed if $\beta 1$ and $\beta 2$ integrins were blocked on the leukocyte surface or when the CCL21 chemokine was sequestered by neutralizing monoclonal antibodies. There are no experimental data providing a direct involvement of CCL2 1 in the activation of $\beta 2$ integrins on DC adhering to LVs in vivo but all the indirect evidences point in this direction.
Interestingly, it has also been described how DC crawling within initial lymphatics depends on ICAM-1 only under inflammatory conditions (55). Of note, no role has been reported yet for ICAM-2 and ICAM-3 on LEC.

PECAM (CD31) is a molecule expressed on most endothelial cells and involved in leukocyte extra- and intravasation (112). LVs express less CD31 (113) than their blood counterparts and it is mostly distributed at cell-cell homotypic interactions (17, 29). Studies made with human cells have shown that blocking this molecule as well as CD99 in CXCL12 treated LEC was able to reduce TEM, both in vitro and on ex vivo tissue cultures (62). PECAM binds to integrin $\alpha v \beta 3$ and $\alpha v \beta 5$ integrins expressed on LVs surface, but care should be taken since PECAM is also expressed by most leukocyte subsets and might mediate homophilic interactions.

L1CAM and ALCAM have been reported to participate in leukocyte transit across LVs, although the experimental evidence provided in this regard is limited. L1CAM is a transmembrane protein widely described in neurons (114). It is also expressed in skin LC and bone marrow-derived DCs (115). L1CAM has been detected on inflamed LVs (52). This integrin ligand mediates both homophilic binding (116) and heterophilic interactions with a number of integrins (i.e., $\beta 3$ and $\beta 5$ ) (117). Recent studies described L1CAM as a protein that mediates DC adhesion and TEM across EC (52), although the molecular mechanisms involved and the relevance of this adhesion molecule are far from being clear.

ALCAM receptor mediates homophilic (ALCAM-ALCAM) or heterophilic (ALCAM-CD6) intercellular adhesion. This receptor is well established as one of the protagonist of leukocyte extravasation across blood vessels, the stabilization of the immunological synapse, and T cell activation (118) Although ALCAM function seems to be of great importance in LV organogenesis, its participation in DC migration has been described in vitro. However the definitive role of DC migration through LVs in lungs was not definitely proved (119).

Other adhesion molecules that do not belong to the family of integrin receptors have been related to DC adhesion to LVs. One of such examples is the LV marker podoplanin. Podoplanin has been described to bind CCL21on LEC surface with high affinity (120), and this interaction has interesting implications for lymphocyte trafficking $(121,122)$. Recent reports demonstrate how podoplanin expressed on LVs surface sustains DC migration and intravasation via the engagement between lectin CLEC-2 as expressed by DC and podoplanin expressed on LVs. CLEC-2 deficiency in DCs impaired their entry into lymphatics and trafficking to and within LN, thereby reducing $\mathrm{T}$ cell priming. Besides, the activation of CLEC- 2 by podoplanin induced Rho A-mediated rearrangements of DCs actin cytoskeleton to promote motility along stromal surfaces (123). This finding is of particular interest because podoplanin is also expressed on other stromal cells and may sustain DC migration in the tissue as well as on or across LVs.

Semaphorins and their receptors, plexins and neuropilins, have been for long known as modulators of normal and pathological angiogenesis and lymphangiogenesis (124). Interestingly, the plexin-A1/sema3A axis has also been described to participate in the migration of DCs to LN. Thus, binding of sema3A to its receptor, 
the complex formed by plexin-A1 and neuropilin-1 expressed on the surface of the LVs, promotes DC contraction of its actomyosin cytoskeleton and squeezing across small gaps (portals) opened on the lymphatic walls (125).

Other receptors such as CLEVER-1 and the mannose receptor have been described to intervene in leukocyte transit across LVs, but their protagonism in this process is far from being clear. CLEVER-1 is a scavenger receptor expressed on LVs (126) that has also been involved in trafficking of adoptively transferred $\mathrm{T}$ lymphocytes from the skin to LNs (127). The Mannose receptor is a C-type lectin carbohydrate binding protein primarily present on the surface of macrophages and DCs that mediates endocytosis (128). The expression of the mannose receptor has also been described on LEC of both afferent and efferent LVs and evidence of impaired migration to LNs of DC lacking its expression has been published $(113,129)$. Still, its importance in vivo has only been shown in lymphatic sinuses inside LNs, where the absence of MR impairs lymphocyte adhesion (130).

\section{THE TRANSIENT SYNAPSES OF LEC AND TRANSMIGRATING LEUKOCYTES: EXCHANGE OF INFORMATION TO SHAPE THE IMMUNE RESPONSE}

Beyond the control of leukocyte traffic to LNs, LECs have demonstrated to show interesting immunomodulatory functions both in afferent LVs and Lymphatic sinuses inside LNs. in these sinuses, LEC constitutively express MHC class II molecules (131) and some co-stimulatory molecules such as ICAM-1 and CD58, but do not promote allogenic T-cell proliferation (132).

In contrast, LEC of lymph node sinuses directly promote peripheral tolerance by antigen presentation to CD8 T cells (133, 134). In this work it was demonstrated that LECs are significant albeit suboptimal APC and promote peripheral tolerance by their lack from key co-stimulatory molecules such as CD80 or 4-1BBL (135) and the rapid up-regulation of significant expression levels of the co-inhibitory molecule PD-L1 (B7-H1) (134). In fact, the exploitation of the ability of LN sinuses to induce tolerance has been recently shown as an escape mechanism for B16 melanoma grafted tumors. Interestingly, the blockade of lymphangiogenic cytokine VEGF-C in this model was able to reduce LEC-induced CD8 T cell tolerance (136). The tolerogenic potentials of LEC in LN sinuses have been recently revised into detail (137).

The possibility of this immunosuppressive/tolerogenic process taking place in peripheral afferent LVs has not been investigated yet. Although IFN $\gamma$ promotes MHC class II expression on dermal LEC without concomitant up-regulation of co-stimulatory molecules (unpublished observations) it is not known whether peripheral LVs can promote tolerance in such conditions. The fact that $\mathrm{CD} 4^{+}$T lymphocytes traffic frequently via lymphatics may set up a possibility of peripheral antigen presentation on LVs, upon CD4 T cell/LEC contact with potential consequences for instance in transplanted organs. It remains to be demonstrated whether LEC serves as a key professional antigen presenting cell for tolerance. Suggestive data on the likeliness of these phenomena has been reported in allogenic transplantation settings, where lymphocyte nodular infiltrations that resemble a tertiary lymphoid organs have been described in grafted organs, around CCL21-podoplanin complexes expressed by the LVs (120). Even more, recent findings demonstrated by intravital imaging approaches how DC crawl rather than roll once inside lymphatic capillaries $(34,55)$ thus favoring extensive and durable contacts between DC and LEC that may be also true for CD4 T cells and LEC. As early mentioned, tight contacts between CD4 T cells or DC and LEC are formed precisely on ICAM-1 enriched microvilli projections (56) that may facilitate a sort of "immune synapse" between leukocytes and LVs. It should not be forgotten that LFA-1 itself is an important co-stimulatory molecule for T cells (138).

In this line, immunomodulatory roles of LEC over DC have already been demonstrated. It has been reported that inflammation induced ICAM-1 is able to decrease the co-stimulation capabilities in immature and TNF- $\alpha$ matured (but not LPS matured) DC. This phenomenon seems to involve Mac-1 integrin ligation on DC (139). These findings raise an intriguing issue since contacts between LEC and DC or T cells do occur both under inflammation and steady-state conditions, it seems that the set of molecules that mediate such intercellular interaction are peculiar for each condition $(55,56)$ and most probably trigger different phenotypes in the LEC-interacting leukocyte subpopulation. For instance, the integrin ligand ICAM-1 is only engaged under inflammation. In this line, we have observed strong phospho-Tyr staining in the areas of contact between LEC Microvilli and DC (unpublished results) supporting that ICAM-1 in this specific context facilitates bidirectional crosstalk between both cell types that tiggers intercellular signals.

Another extracellular receptor involved in LEC-shaping of the immune response is CD137/4-1BB molecule. As already mentioned, we have recently identified CD137 (4-1BB) expression on inflamed LVs. The ligation of this molecule on LEC promotes CCL21 up-regulation (81) and increased DC transmigration. CD137-Ligand reverse signaling would in turn promote the increased expression of co-stimulatory molecules and chemokine receptors on migrating APCs (140). This system may be a first example of molecules denoting inflammation and subsequently fine-tuning lymphocyte activation and migration via afferent LVs. It is tempting to speculate that transit of an activated leukocyte sensitizes for subsequent transit events by a variety of immunologically relevant ligand receptor pairs, including other members of the TNF and TNFR families.

\section{OPPORTUNITIES FOR THERAPEUTIC INTERVENTION AT THE INTERFACE BETWEEN LEC AND IMMUNE SYSTEM CELLS ENHANCING LEUKOCYTE MIGRATION TO INCREASE VACCINE EFFICIENCY}

Dendritic cell based vaccines often given subcutaneously constitute an interesting approach for the treatment of cancer (141). Immunization is attempted toward defined antigens shared by tumors or against individual neoantigens product of the altered genome of individual malignancies. The latter is very attractive and encompasses strategies varying from DC loading with mRNA, tumor lysates to intratumoral DC injections.

The intradermal route of administration seems to be more effective in eliciting immune responses (142), while one of the key limitations for its efficacy seems to be DC arrival to LNs $(143,144)$. Since intravasation in LVs is a key step in the migration of DCs 
to $\mathrm{LN}$, intervention in this particular step may provide increased efficiency in DC therapies. It has been reported that preconditioning the area of injection by promoting for example, acute inflammation promotes migration and maturation on DC vaccination when TLR agonist poly I:C is used as an adjuvant $(145,146)$. The TLR7 agonist imiquimod has also been applied to the skin at the vaccination site with a similar purpose (147). Pro-inflammatory cytokines have proved to be good local adjuvants (148).

Other methods may provide also good preconditioning for injection sites, as local irradiation (149) or laser illumination (150) which additionally enhances migratory possibilities by increasing the degradation of the basal membrane of the vessels. The preparation of DC is also particularly relevant in the migration and efficacy of DC vaccines (141). By including different cytokines in DC maturation cocktails, their migration to LNs can also be enhanced. For instance IFN-alpha $(53,151)$ induces increments in the expression of chemokine receptors one LEC and integrin activation on DC surface. The strongest stimulus for CCR7 expression and functionality is the lipid mediator PGE2 (152, 153). However, many immunosuppressive functions of PGE2 on DC discourage the use of this prostaglandin in DC maturation cocktails.

\section{THE ROLE OF LYMPHATICS ON INFLAMMATORY DISEASES}

In the last few years it has been shown how the plasticity of LV in response to inflammation can also contribute to the progression of diseases whose mechanisms involve chronic inflammation, as some autoimmune diseases (154).

Increased LV density has been observed in psoriatic skin (155) and rheumatoid arthritis lesions in mice joints (156). As previously mentioned, there is increased LV presence in kidney transplants and their secretion of CCL21 promotes DC migration and alloantigen response and rejection (120). Diminishing (157) or normalizing lymphangiogenesis by VEGFR stimulation (27) is considered a promising treatment to control chronic inflammation.

There is already some evidence for pharmacological treatments directed toward leukocyte intravasation on LVs that may help in the treatment of these diseases. For instance, the blockade of DC traffic with anti-VEGF antibodies reduces inflammation (158) and rejection of mice corneas. Interestingly, in a heart transplantation model, blockade of VEGF with antibodies has proved to decrease inflammation by a mechanism directly dependent on CCL21 production by LVs (159).

While the role of blood vessels in leukocyte traffic is known in great molecular detail, that of LV is less well understood. Regulation of adhesiveness and chemotaxis in blood vessels can be interfered for the sake of suppressing inflammation in multiple sclerosis or transplantation with anti-VLA-4 mAb. In fact, it is quite possible that the S1P antagonist sphingolimod exerts an important effect on memory lymphocyte egress from the inflamed territory suffering autoimmunity toward LN.

In our view there is also much potential in pharmacological manipulation of the CCR7 axis (160). From a drug development perspective is not an easy target but it certainly would provide a tool to disorient recirculation of pathogenic $\mathrm{T}$ lymphocytes and limit the arrival of immunogenic autoantigens to lymphoid tissue.

\section{CONCLUDING REMARIKS}

Research performed mainly in the last 10 years regarding leukocyte migration via afferent LVs has unraveled that the process is highly regulated and more complex than originally expected. Importantly, new incisive experimental procedures including in vivo imaging have provided detailed knowledge of the process. Some interesting and unexpected molecular players including chemokines and adhesion molecules have been identified as gatekeepers of LV intravasation and intriguing data about a tight relationship between LEC and leukocytes have been reported. Knowledge on the regulation of DC migration out of peripheral tissue is beginning to be exploited for vaccination, but we are only starting to learn the pathological and therapeutic implications that leukocyte-LVs contact may have. Especially, the field of the tissue-egressing mechanisms of $\mathrm{T}$ Lymphocytes remains neglected. We believe that a more in depth knowledge of these leukocyte-LVs interactions may provide interesting cues or potential targets for chronic inflammation. Migration through LVs must not be observed as a passive drain but as process that is highly regulated by changes in the tissue homeostasis, and that may help to shape immune responses both under steady-state and inflammatory conditions.

\section{ACKNOWLEDGMENTS}

Alvaro Teijeira, Ana Rouzaut and Ignacio Melero have written the drafts, designed, and prepared the figures and approved the final version.

\section{REFERENCES}

1. Pepper MS, Skobe M. Lymphatic endothelium: morphological, molecular and functional properties. J Cell Biol (2003) 163:209-13. doi:10.1083/jcb. 200308082

2. Forster R, Braun A, Worbs T. Lymph node homing of T cells and dendritic cells via afferent lymphatics. Trends Immunol (2012) 33:271-80. doi:10.1016/j. it.2012.02.007

3. Mackay CR, Marston WL, Dudler L. Naive and memory T cells show distinct pathways of lymphocyte recirculation. J Exp Med (1990) 171:801-17. doi:10.1084/jem.171.3.801

4. Young AJ. The physiology of lymphocyte migration through the single lymph node in vivo. Semin Immunol (1999) 11:73-83. doi:10.1006/smim.1999.0163

5. Tomura M, Honda T, Tanizaki H, Otsuka A, Egawa G, Tokura Y, et al. Activated regulatory $\mathrm{T}$ cells are the major $\mathrm{T}$ cell type emigrating from the skin during a cutaneous immune response in mice. J Clin Invest (2010) 120:883-93. doi:10.1172/JCI40926

6. Drexhage HA, Mullink H, De Groot J, Clarke J, Balfour BM. A study of cells present in peripheral lymph of pigs with special reference to a type of cell resembling the Langerhans cell. Cell Tissue Res (1979) 202:407-30. doi:10.1007/BF00220434

7. Spry CJ, Pflug AJ, Janossy G, Humphrey JH. Large mononuclear (veiled) cells like 'Ia-like' membrane antigens in human afferent lympn. Clin Exp Immunol (1980) 39:750-5.

8. Pugh CW, Macpherson GG, Steer HW. Characterization of nonlymphoid cells derived from rat peripheral lymph. J Exp Med (1983) 157:1758-79. doi:10.1084/jem.157.6.1758

9. Mayrhofer G, Holt PG, Papadimitriou JM. Functional characteristics of the veiled cells in afferent lymph from the rat intestine. Immunology (1986) 58:379-87.

10. Heath WR, Carbone FR. Dendritic cell subsets in primary and secondary $\mathrm{T}$ cell responses at body surfaces. Nat Immunol (2009) 10:1237-44. doi:10. 1038/ni.1822

11. Ohl L, Mohaupt M, Czeloth N, Hintzen G, Kiafard Z, Zwirner J, et al. CCR7 governs skin dendritic cell migration under inflammatory and steady-state conditions. Immunity (2004) 21:279-88. doi:10.1016/j.immuni.2004.06.014 
12. Scheinecker C, Mchugh R, Shevach EM, Germain RN. Constitutive presentation of a natural tissue autoantigen exclusively by dendritic cells in the draining lymph node. J Exp Med (2002) 196:1079-90. doi:10.1084/jem.20020991

13. Mayerova D, Parke EA, Bursch LS, Odumade OA, Hogquist KA. Langerhans cells activate naive self-antigen-specific CD8 T cells in the steady state. Immunity (2004) 21:391-400. doi:10.1016/j.immuni.2004.07.019

14. Ginhoux F, Collin MP, Bogunovic M, Abel M, Leboeuf M, Helft J, et al. Bloodderived dermal Langerin + dendritic cells survey the skin in the steady state. $J$ Exp Med (2007) 204:3133-46. doi:10.1084/jem.20071733

15. Wendland M, Willenzon S, Kocks J, Davalos-Misslitz AC, Hammerschmidt SI, Schumann K, et al. Lymph node T cell homeostasis relies on steady state homing of dendritic cells. Immunity (2011) 35:945-57. doi:10.1016/j.immuni.2011. 10.017

16. Kripke ML, Munn CG, Jeevan A, Tang JM, Bucana C. Evidence that cutaneous antigen-presenting cells migrate to regional lymph nodes during contact sensitization. J Immunol (1990) 145:2833-8.

17. Baluk P, Fuxe J, Hashizume H, Romano T, Lashnits E, Butz S, et al. Functionally specialized junctions between endothelial cells of lymphatic vessels. J Exp Med (2007) 204:2349-62. doi:10.1084/jem.20062596

18. Casley-Smith JR, Florey HW. The structure of normal small lymphatics. Q J Exp Physiol Cogn Med Sci (1961) 46:101-6.

19. Castenholz A. Functional microanatomy of initial lymphatics with special consideration of the extracellular matrix. Lymphology (1998) 31:101-18.

20. Pflicke $H$, Sixt M. Preformed portals facilitate dendritic cell entry into afferent lymphatic vessels. J Exp Med (2009) 206:2925-35. doi:10.1084/jem.20091739

21. Yao LC, Baluk P, Srinivasan RS, Oliver G, Mcdonald DM. Plasticity of button-like junctions in the endothelium of airway lymphatics in development and inflammation. Am J Pathol (2012) 180:2561-75. doi:10.1016/j.ajpath.2012. 02.019

22. Ristimaki A, Narko K, Enholm B, Joukov V, Alitalo K. Proinflammatory cytokines regulate expression of the lymphatic endothelial mitogen vascular endothelial growth factor-C. J Biol Chem (1998) 273:8413-8. doi:10.1074/jbc. 273.14.8413

23. Kang S, Lee SP, Kim KE, Kim HZ, Memet S, Koh GY. Toll-like receptor 4 in lymphatic endothelial cells contributes to LPS-induced lymphangiogenesis by chemotactic recruitment of macrophages. Blood (2009) 113:2605-13. doi:10.1182/blood-2008-07-166934

24. Makinen T, Jussila L, Veikkola T, Karpanen T, Kettunen MI, Pulkkanen KJ, et al. Inhibition of lymphangiogenesis with resulting lymphedema in transgenic mice expressing soluble VEGF receptor-3. Nat Med (2001) 7:199-205. doi:10.1038/84651

25. Kajiya K, Sawane M, Huggenberger R, Detmar M. Activation of the VEGFR3 pathway by VEGF-C attenuates UVB-induced edema formation and skin inflammation by promoting lymphangiogenesis. J Invest Dermatol (2009) 129:1292-8. doi:10.1038/jid.2008.351

26. Flister MJ, Wilber A, Hall KL, Iwata C, Miyazono K, Nisato RE, et al. Inflammation induces lymphangiogenesis through up-regulation of VEGFR-3 mediated by NF-kappaB and Proxl. Blood (2010) 115:418-29. doi:10.1182/blood-200812- 196840

27. Huggenberger R, Ullmann S, Proulx ST, Pytowski B, Alitalo K, Detmar M. Stimulation of lymphangiogenesis via VEGFR-3 inhibits chronic skin inflammation. J Exp Med (2010) 207:2255-69. doi:10.1084/jem.20100559

28. Angeli V, Randolph GJ. Inflammation, lymphatic function, and dendritic cell migration. Lymphat Res Biol (2006) 4:217-28. doi:10.1089/lrb.2006.4406

29. Johnson LA, Clasper S, Holt AP, Lalor PF, Baban D, Jackson DG. An inflammation-induced mechanism for leukocyte transmigration across lymphatic vessel endothelium. J Exp Med (2006) 203:2763-77. doi:10.1084/jem. 20051759

30. Vigl B, Aebischer D, Nitschke M, Iolyeva M, Rothlin T, Antsiferova O, et al. Tissue inflammation modulates gene expression of lymphatic endothelial cells and dendritic cell migration in a stimulus-dependent manner. Blood (2011) 118:205-15. doi:10.1182/blood-2010-12-326447

31. Johnson LA, Jackson DG. Inflammation-induced secretion of CCL21 in lymphatic endothelium is a key regulator of integrin-mediated dendritic cell transmigration. Int Immunol (2010) 22:839-49. doi:10.1093/intimm/ dxq435

32. Zampell JC, Avraham T, Yoder N, Fort N, Yan A, Weitman ES, et al. Lymphatic function is regulated by a coordinated expression of lymphangiogenic and anti-lymphangiogenic cytokines. Am J Physiol Cell Physiol (2012) 302:C392-404. doi:10.1152/ajpcell.00306.2011

33. Miteva DO, Rutkowski JM, Dixon JB, Kilarski W, Shields JD, Swartz MA. Transmural flow modulates cell and fluid transport functions of lymphatic endothelium. Circ Res (2010) 106:920-31. doi:10.1161/CIRCRESAHA.109.207274

34. Tal O, Lim HY, Gurevich I, Milo I, Shipony Z, Ng LG, et al. DC mobilization from the skin requires docking to immobilized CCL21 on lymphatic endothelium and intralymphatic crawling. J Exp Med (2011) 208:2141-53. doi:10.1084/jem.20102392

35. Alon R, Dustin ML. Force as a facilitator of integrin conformational changes during leukocyte arrest on blood vessels and antigen-presenting cells. Immunity (2007) 26:17-27. doi:10.1016/j.immuni.2007.01.002

36. Kunder CA, St John AL, Li G, Leong KW, Berwin B, Staats HF, et al. Mast cellderived particles deliver peripheral signals to remote lymph nodes. J Exp Med (2009) 206:2455-67. doi:10.1084/jem.20090805

37. Kunder CA, St John AL, Abraham SN. Mast cell modulation of the vascular and lymphatic endothelium. Blood (2011) 118:5383-93. doi:10.1182/blood-201107-358432

38. Angeli V, Ginhoux F, Llodra J, Quemeneur L, Frenette PS, Skobe M, et al. B celldriven lymphangiogenesis in inflamed lymph nodes enhances dendritic cell mobilization. Immunity (2006) 24:203-15. doi:10.1016/j.immuni.2006.01.003

39. Halin C, Detmar M. An unexpected connection: lymph node lymphangiogenesis and dendritic cell migration. Immunity (2006) 24:129-31. doi:10.1016/j. immuni.2006.01.011

40. Bromley SK, Thomas SY, Luster AD. Chemokine receptor CCR7 guides T cell exit from peripheral tissues and entry into afferent lymphatics. Nat Immunol (2005) 6:895-901. doi:10.1038/ni1240

41. Debes GF, Arnold CN, Young AJ, Krautwald S, Lipp M, Hay JB, et al. Chemokine receptor CCR7 required for T lymphocyte exit from peripheral tissues. Nat Immunol (2005) 6:889-94. doi:10.1038/ni1238

42. Brown MN, Fintushel SR, Lee MH, Jennrich S, Geherin SA, Hay JB, et al. Chemoattractant receptors and lymphocyte egress from extralymphoid tissue: changing requirements during the course of inflammation. J Immunol (2010) 185:4873-82. doi:10.4049/jimmunol.1000676

43. Yang CW, Strong BS, Miller MJ, Unanue ER. Neutrophils influence the level of antigen presentation during the immune response to protein antigens in adjuvants. J Immunol (2010) 185:2927-34. doi:10.4049/jimmunol.1001289

44. Beauvillain C, Cunin P, Doni A, Scotet M, Jaillon S, Loiry ML, et al. CCR7 is involved in the migration of neutrophils to lymph nodes. Blood (2011) 117:1196-204. doi:10.1182/blood-2009-11-254490

45. Alfaro C, Suarez N, Onate C, Perez-Gracia JL, Martinez-Forero I, HervasStubbs S, et al. Dendritic cells take up and present antigens from viable and apoptotic polymorphonuclear leukocytes. PLoS One (2011) 6:e29300. doi:10.1371/journal.pone.0029300

46. Podgrabinska S, Braun P, Velasco P, Kloos B, Pepper MS, Skobe M. Molecular characterization of lymphatic endothelial cells. Proc Natl Acad Sci U S A (2002) 99:16069-74. doi:10.1073/pnas.242401399

47. Lee S, Choi I, Hong YK. Heterogeneity and plasticity of lymphatic endothelial cells. Semin Thromb Hemost (2010) 36:352-61. doi:10.1055/s-0030- 1253457

48. Ando T, Jordan P, Joh T, Wang Y, Jennings MH, Houghton J, et al. Isolation and characterization of a novel mouse lymphatic endothelial cell line: SV-LEC. Lymphat Res Biol (2005) 3:105-15. doi:10.1089/lrb.2005.3.105

49. Sironi M, Conti A, Bernasconi S, Fra AM, Pasqualini F, Nebuloni M, et al. Generation and characterization of a mouse lymphatic endothelial cell line. Cell Tissue Res (2006) 325:91-100. doi:10.1007/s00441-006-0171-y

50. Kang J, Ramu S, Lee S, Aguilar B, Ganesan SK, Yoo J, et al. Phosphate-buffered saline-based nucleofection of primary endothelial cells. Anal Biochem (2009) 386:251-5. doi:10.1016/j.ab.2008.12.021

51. Zheng W, Tammela T, Yamamoto M, Anisimov A, Holopainen T, Kaijalainen S, et al. Notch restricts lymphatic vessel sprouting induced by vascular endothelial growth factor. Blood (2011) 118:1154-62. doi:10.1182/blood-2010-11-317800

52. Maddaluno L, Verbrugge SE, Martinoli C, Matteoli G, Chiavelli A, Zeng Y, et al. The adhesion molecule L1 regulates transendothelial migration and trafficking of dendritic cells. J Exp Med (2009) 206:623-35. doi:10.1084/jem.20081211

53. Rouzaut A, Garasa S, Teijeira A, Gonzalez I, Martinez-Forero I, Suarez N, et al. Dendritic cells adhere to and transmigrate across lymphatic endothelium in response to IFN-alpha. Eur J Immunol (2010) 40:3054-63. doi:10.1002/eji. 201040523 
54. Ledgerwood LG, Lal G, Zhang N, Garin A, Esses SJ, Ginhoux F, et al. The sphingosine 1-phosphate receptor 1 causes tissue retention by inhibiting the entry of peripheral tissue T lymphocytes into afferent lymphatics. Nat Immunol (2008) 9:42-53. doi:10.1038/ni1534

55. Nitschke M, Aebischer D, Abadier M, Haener S, Lucic M, Vigl B, et al. Differential requirement for ROCK in dendritic cell migration within lymphatic capillaries in steady-state and inflammation. Blood (2012) 120:2249-58. doi:10.1182/blood-2012-03-417923

56. Teijeira A, Garasa S, Pelaez R, Azpilikueta A, Ochoa C, Marre D, et al. Lymphatic endothelium forms integrin-engaging 3D structures during DC transit across inflamed lymphatic vessels. J Invest Dermatol (2013) 133:227685. doi:10.1038/jid.2013.152

57. Khuon S, Liang L, Dettman RW, Sporn PH, Wysolmerski RB, Chew TL. Myosin light chain kinase mediates transcellular intravasation of breast cancer cells through the underlying endothelial cells: a three-dimensional FRET study. J Cell Sci (2010) 123:431-40. doi:10.1242/jcs.053793

58. Shin Y, Han S, Jeon JS, Yamamoto K, Zervantonakis IK, Sudo R, et al. Microfluidic assay for simultaneous culture of multiple cell types on surfaces or within hydrogels. Nat Protoc (2012) 7:1247-59. doi:10.1038/nprot.2012.051

59. Zervantonakis IK, Hughes-Alford SK, Charest JL, Condeelis JS, Gertler FB, Kamm RD. Three-dimensional microfluidic model for tumor cell intravasation and endothelial barrier function. Proc Natl Acad Sci US A (2012) 109:13515-20. doi:10.1073/pnas.1210182109

60. Larsen CP, Steinman RM, Witmer-Pack M, Hankins DF, Morris PJ, Austyn JM. Migration and maturation of Langerhans cells in skin transplants and explants. J Exp Med (1990) 172:1483-93. doi:10.1084/jem.172.5.1483

61. Lammermann T, Bader BL, Monkley SJ, Worbs T, Wedlich-Soldner R, Hirsch K, et al. Rapid leukocyte migration by integrin-independent flowing and squeezing. Nature (2008) 453:51-5. doi:10.1038/nature06887

62. Torzicky M, Viznerova P, Richter S, Strobl H, Scheinecker C, Foedinger D, et al. Platelet endothelial cell adhesion molecule-1 (PECAM-1/CD31) and CD99 are critical in lymphatic transmigration of human dendritic cells. J Invest Dermatol (2012) 132:1149-57. doi:10.1038/jid.2011.420

63. Randolph GJ, Angeli V, Swartz MA. Dendritic-cell trafficking to lymph nodes through lymphatic vessels. Nat Rev Immunol (2005) 5:617-28. doi:10.1038/ nri 1670

64. Thomas WR, Edwards AJ, Watkins MC, Asherson GL. Distribution of immunogenic cells after painting with the contact sensitizers fluorescein isothiocyanate and oxazolone. Different sensitizers form immunogenic complexes with different cell populations. Immunology (1980) 39:21-7.

65. Randolph GJ, Inaba K, Robbiani DF, Steinman RM, Muller WA. Differentiation of phagocytic monocytes into lymph node dendritic cells in vivo. Immunity (1999) 11:753-61. doi:10.1016/S1074-7613(00)80149-1

66. Kimber I, Cumberbatch M. Stimulation of Langerhans cell migration by tumor necrosis factor alpha (TNF-alpha). J Invest Dermatol (1992) 99:48S-50S. doi:10.1111/1523-1747.ep12668986

67. Martin-Fontecha A, Sebastiani S, Hopken UE, Uguccioni M, Lipp M, Lanzavecchia A, et al. Regulation of dendritic cell migration to the draining lymph node: impact on T lymphocyte traffic and priming. J Exp Med (2003) 198:615-21. doi:10.1084/jem. 20030448

68. Choi I, Chung HK, Ramu S, Lee HN, Kim KE, Lee S, et al. Visualization of lymphatic vessels by Proxl-promoter directed GFP reporter in a bacterial artificial chromosome-based transgenic mouse. Blood (2011) 117:362-5. doi:10.1182/blood-2010-07-298562

69. Hagerling R, Pollmann C, Kremer L, Andresen V, Kiefer F. Intravital two-photon microscopy of lymphatic vessel development and function using a transgenic Proxl promoter-directed mOrange2 reporter mouse. Biochem Soc Trans (2011) 39:1674-81. doi:10.1042/BST20110722

70. Martinez-Corral I, Olmeda D, Dieguez-Hurtado R, Tammela T, Alitalo K, Ortega S. In vivo imaging of lymphatic vessels in development, wound healing, inflammation, and tumor metastasis. Proc Natl Acad Sci U S A (2012) 109:6223-8. doi:10.1073/pnas.1115542109

71. Svingen T, Francois M, Wilhelm D, Koopman P. Three-dimensional imaging of Proxl-EGFP transgenic mouse gonads reveals divergent modes of lymphangiogenesis in the testis and ovary. PLoS One (2012) 7:e52620. doi:10.1371/ journal.pone.0052620

72. Truman LA, Bentley KL, Smith EC, Massaro SA, Gonzalez DG, Haberman $\mathrm{AM}$, et al. ProxTom lymphatic vessel reporter mice reveal Proxl expression in the adrenal medulla, megakaryocytes, and platelets. Am J Pathol (2012) 180:1715-25. doi:10.1016/j.ajpath.2011.12.026

73. Kilarski WW, Guc E, Teo JC, Oliver SR, Lund AW, Swartz MA. Intravital immunofluorescence for visualizing the microcirculatory and immune microenvironments in the mouse ear dermis. PLoS One (2013) 8:e57135. doi:10.1371/journal.pone.0057135

74. Sallusto F, Schaerli P, Loetscher P, Schaniel C, Lenig D, Mackay CR, et al. Rapid and coordinated switch in chemokine receptor expression during dendritic cell maturation. Eur J Immunol (1998) 28:2760-9. doi:10.1002/(SICI)15214141(199809)28:09<2760::AID-IMMU2760>3.0.CO;2-N

75. Kriehuber E, Breiteneder-Geleff S, Groeger M, Soleiman A, Schoppmann SF, Stingl G, et al. Isolation and characterization of dermal lymphatic and blood endothelial cells reveal stable and functionally specialized cell lineages. J Exp Med (2001) 194:797-808. doi:10.1084/jem.194.6.797

76. Bao X, Moseman EA, Saito H, Petryniak B, Thiriot A, Hatakeyama S, et al. Endothelial heparan sulfate controls chemokine presentation in recruitment of lymphocytes and dendritic cells to lymph nodes. Immunity (2010) 33:817-29. doi:10.1016/j.immuni.2010.10.018

77. Schumann K, Lammermann T, Bruckner M, Legler DF, Polleux J, Spatz JP, et al. Immobilized chemokine fields and soluble chemokine gradients cooperatively shape migration patterns of dendritic cells. Immunity (2010) 32:703-13. doi:10.1016/j.immuni.2010.04.017

78. Weber M, Hauschild R, Schwarz J, Moussion C, De Vries I, Legler DF, et al. Interstitial dendritic cell guidance by haptotactic chemokine gradients. Science (2013) 339:328-32. doi:10.1126/science.1228456

79. Martin-Fontecha A, Lanzavecchia A, Sallusto F. Dendritic cell migration to peripheral lymph nodes. Handb Exp Pharmacol (2009) 188:31-49. doi:10.1007/ 978-3-540-71029-5_2

80. Eich C, De Vries IJ, Linssen PC, De Boer A, Boezeman JB, Figdor CG, et al. The lymphoid chemokine CCL21 triggers LFA-1 adhesive properties on human dendritic cells. Immunol Cell Biol (2011) 89:458-65. doi:10.1038/icb.2010.103

81. Teijeira A, Palazon A, Garasa S, Marre D, Auba C, Rogel A, et al. CD137 on inflamed lymphatic endothelial cells enhances CCL21-guided migration of dendritic cells. FASEB J (2012) 26:3380-92. doi:10.1096/fj.11-201061

82. Shields JD, Fleury ME, Yong C, Tomei AA, Randolph GJ, Swartz MA. Autologous chemotaxis as a mechanism of tumor cell homing to lymphatics via interstitial flow and autocrine CCR7 signaling. Cancer Cell (2007) 11:526-38. doi:10.1016/j.ccr.2007.04.020

83. Sallusto F, Lenig D, Forster R, Lipp M, Lanzavecchia A. Two subsets of memory T lymphocytes with distinct homing potentials and effector functions. Nature (1999) 401:708-12. doi:10.1038/44385

84. Masopust D, Schenkel JM. The integration of T cell migration, differentiation and function. Nat Rev Immunol (2013) 13:309-20. doi:10.1038/nri3442

85. Kabashima K, Shiraishi N, Sugita K, Mori T, Onoue A, Kobayashi M, et al. CXCL12-CXCR4 engagement is required for migration of cutaneous dendritic cells. Am J Pathol (2007) 171:1249-57. doi:10.2353/ajpath.2007.070225

86. Kabashima K, Sugita K, Shiraishi N, Tamamura H, Fujii N, Tokura Y. CXCR4 engagement promotes dendritic cell survival and maturation. Biochem Biophys Res Commun (2007) 361:1012-6. doi:10.1016/j.bbrc.2007.07.128

87. Spiegel S, Milstien S. The outs and the ins of sphingosine-1-phosphate in immunity. Nat Rev Immunol (2011) 11:403-15. doi:10.1038/nri2974

88. Matloubian M, Lo CG, Cinamon G, Lesneski MJ, Xu Y, Brinkmann V, et al. Lymphocyte egress from thymus and peripheral lymphoid organs is dependent on S1P receptor 1. Nature (2004) 427:355-60. doi:10.1038/nature02284

89. Pappu R, Schwab SR, Cornelissen I, Pereira JP, Regard JB, Xu Y, et al. Promotion of lymphocyte egress into blood and lymph by distinct sources of sphingosine1-phosphate. Science (2007) 316:295-8. doi:10.1126/science.1139221

90. Pham TH, Baluk P, Xu Y, Grigorova I, Bankovich AJ, Pappu R, et al. Lymphatic endothelial cell sphingosine kinase activity is required for lymphocyte egress and lymphatic patterning. J Exp Med (2010) 207:17-27. doi:10.1084/ jem.20091619

91. Czeloth N, Bernhardt G, Hofmann F, Genth H, Forster R. Sphingosine-1phosphate mediates migration of mature dendritic cells. J Immunol (2005) 175:2960-7.

92. Gollmann G, Neuwirt H, Tripp CH, Mueller H, Konwalinka G, Heufler C, et al. Sphingosine-1-phosphate receptor type-1 agonism impairs blood dendritic cell chemotaxis and skin dendritic cell migration to lymph nodes under inflammatory conditions. Int Immunol (2008) 20:911-23. doi:10.1093/intimm/dxn050 
93. Rathinasamy A, Czeloth N, Pabst O, Forster R, Bernhardt G. The origin and maturity of dendritic cells determine the pattern of sphingosine 1-phosphate receptors expressed and required for efficient migration. J Immunol (2010) 185:4072-81. doi:10.4049/jimmunol.1000568

94. Graler MH, Goetzl EJ. The immunosuppressant FTY720 down-regulates sphingosine 1-phosphate G-protein-coupled receptors. FASEB J (2004) 18: 551-3. doi:10.1096/fj.03-0910fje

95. Shiow LR, Rosen DB, Brdickova N, Xu Y, An J, Lanier LL, et al. CD69 acts downstream of interferon-alpha/beta to inhibit S1P1 and lymphocyte egress from lymphoid organs. Nature (2006) 440:540-4. doi:10.1038/nature04606

96. Bankovich AJ, Shiow LR, Cyster JG. CD69 suppresses sphingosine 1-phosphate receptor-1 (S1P1) function through interaction with membrane helix 4. J Biol Chem (2010) 285:22328-37. doi:10.1074/jbc.M110.123299

97. Lamana A, Martin P, De La Fuente H, Martinez-Munoz L, Cruz-Adalia A, Ramirez-Huesca M, et al. CD69 modulates sphingosine-1-phosphate-induced migration of skin dendritic cells. J Invest Dermatol (2011) 131:1503-12. doi:10.1038/jid.2011.54

98. Ahmed SR, Mcgettrick HM, Yates CM, Buckley CD, Ratcliffe MJ, Nash GB, et al. Prostaglandin D2 regulates CD4+ memory T cell trafficking across blood vascular endothelium and primes these cells for clearance across lymphatic endothelium. J Immunol (2011) 187:1432-9. doi:10.4049/jimmunol.1100299

99. Johnson LA, Jackson DG. The chemokine CX3CL1 promotes trafficking of dendritic cells through inflamed lymphatics. J Cell Sci (2013) 126:5259-70. doi: $10.1242 /$ ics. 135343

100. Fra AM, Locati M, Otero K, Sironi M, Signorelli P, Massardi ML, et al. Cutting edge: scavenging of inflammatory $\mathrm{CC}$ chemokines by the promiscuous putatively silent chemokine receptor D6. J Immunol (2003) 170:2279-82.

101. Weber M, Blair E, Simpson CV, O'Hara M, Blackburn PE, Rot A, et al. The chemokine receptor D6 constitutively traffics to and from the cell surface to internalize and degrade chemokines. Mol Biol Cell (2004) 15:2492-508. doi:10.1091/mbc.E03-09-0634

102. Bonecchi R, Locati M, Galliera E, Vulcano M, Sironi M, Fra AM, et al. Differential recognition and scavenging of native and truncated macrophage-derived chemokine (macrophage-derived chemokine/CC chemokine ligand 22) by the D6 decoy receptor. J Immunol (2004) 172:4972-6.

103. Savino B, Borroni EM, Torres NM, Proost P, Struyf S, Mortier A, et al. Recognition versus adaptive up-regulation and degradation of $\mathrm{CC}$ chemokines by the chemokine decoy receptor D6 are determined by their N-terminal sequence. $J$ Biol Chem (2009) 284:26207-15. doi:10.1074/jbc.M109.029249

104. McKimmie CS, Singh MD, Hewit K, Lopez-Franco O, Le Brocq M, Rose-John S, et al. An analysis of the function and expression of D6 on lymphatic endothelial cells. Blood (2013) 121:3768-77. doi:10.1182/blood-2012-04-425314

105. Lee KM, Mckimmie CS, Gilchrist DS, Pallas KJ, Nibbs RJ, Garside P, et al. D6 facilitates cellular migration and fluid flow to lymph nodes by suppressing lymphatic congestion. Blood (2011) 118:6220-9. doi:10.1182/blood-2011-03344044

106. Vicente-Manzanares M, Ma X, Adelstein RS, Horwitz AR. Non-muscle myosin II takes centre stage in cell adhesion and migration. Nat Rev Mol Cell Biol (2009) 10:778-90. doi:10.1038/nrm 2786

107. Ma J, Wang JH, Guo YJ, Sy MS, Bigby M. In vivo treatment with anti-ICAM1 and anti-LFA-1 antibodies inhibits contact sensitization-induced migration of epidermal Langerhans cells to regional lymph nodes. Cell Immunol (1994) 158:389-99. doi:10.1006/cimm.1994.1285

108. Xu H, Guan H, Zu G, Bullard D, Hanson J, Slater M, et al. The role of ICAM-1 molecule in the migration of Langerhans cells in the skin and regional lymph node. Eur J Immunol (2001) 31:3085-93. doi:10.1002/1521-4141(2001010)31: 10<3085::AID-IMMU3085>3.0.CO;2-B

109. Pegu A, Qin S, Fallert Junecko BA, Nisato RE, Pepper MS, Reinhart TA. Human lymphatic endothelial cells express multiple functional TLRs. J Immunol (2008) 180:3399-405.

110. Barreiro O, Yanez-Mo M, Serrador JM, Montoya MC, Vicente-Manzanares M, Tejedor R, et al. Dynamic interaction of VCAM-1 and ICAM-1 with moesin and ezrin in a novel endothelial docking structure for adherent leukocytes. $J$ Cell Biol (2002) 157:1233-45. doi:10.1083/jcb.200112126

111. Carman CV, Jun CD, Salas A, Springer TA. Endothelial cells proactively form microvilli-like membrane projections upon intercellular adhesion molecule 1 engagement of leukocyte LFA-1. J Immunol (2003) 171:6135-44.
112. Nourshargh S, Hordijk PL, Sixt M. Breaching multiple barriers: leukocyte motility through venular walls and the interstitium. Nat Rev Mol Cell Biol (2010) 11:366-78. doi:10.1038/nrm2889

113. Hirakawa S, Hong YK, Harvey N, Schacht V, Matsuda K, Libermann T, et al. Identification of vascular lineage-specific genes by transcriptional profiling of isolated blood vascular and lymphatic endothelial cells. Am J Pathol (2003) 162:575-86. doi:10.1016/S0002-9440(10)63851-5

114. Maness PF, Schachner M. Neural recognition molecules of the immunoglobulin superfamily: signaling transducers of axon guidance and neuronal migration. Nat Neurosci (2007) 10:19-26. doi:10.1038/nn0207-263b

115. Pancook JD, Reisfeld RA, Varki N, Vitiello A, Fox RI, Montgomery AM. Expression and regulation of the neural cell adhesion molecule $\mathrm{L} 1$ on human cells of myelomonocytic and lymphoid origin. J Immunol (1997) 158:4413-21.

116. Wei CH, Ryu SE. Homophilic interaction of the L1 family of cell adhesion molecules. Exp Mol Med (2012) 44:413-23. doi:10.3858/emm.2012.44.7.050

117. Felding-Habermann B, Silletti S, Mei F, Siu CH, Yip PM, Brooks PC, et al. A single immunoglobulin-like domain of the human neural cell adhesion molecule L1 supports adhesion by multiple vascular and platelet integrins. J Cell Biol (1997) 139:1567-81. doi:10.1083/jcb.139.6.1567

118. Gilsanz A, Sanchez-Martin L, Gutierrez-Lopez MD, Ovalle S, MachadoPineda Y, Reyes R, et al. ALCAM/CD166 adhesive function is regulated by the tetraspanin CD9. Cell Mol Life Sci (2013) 70:475-93. doi:10.1007/s00018-0121132-0

119. Iolyeva M, Karaman S, Willrodt AH, Weingartner S, Vigl B, Halin C. Novel role for ALCAM in lymphatic network formation and function. FASEB J (2013) 27:978-90. doi:10.1096/fj.12-217844

120. Kerjaschki D, Regele HM, Moosberger I, Nagy-Bojarski K, Watschinger B, Soleiman A, et al. Lymphatic neoangiogenesis in human kidney transplants is associated with immunologically active lymphocytic infiltrates. J Am Soc Nephrol (2004) 15:603-12. doi:10.1097/01.ASN.0000113316.52371.2E

121. Luther SA, Tang HL, Hyman PL, Farr AG, Cyster JG. Coexpression of the chemokines ELC and SLC by T zone stromal cells and deletion of the ELC gene in the plt/plt mouse. Proc Natl Acad Sci U S A (2000) 97:12694-9. doi:10.1073/pnas.97.23.12694

122. Bajenoff M, Egen JG, Koo LY, Laugier JP, Brau F, Glaichenhaus N, et al. Stromal cell networks regulate lymphocyte entry, migration, and territoriality in lymph nodes. Immunity (2006) 25:989-1001. doi:10.1016/j.immuni.2006.10.011

123. Acton SE, Astarita JL, Malhotra D, Lukacs-Kornek V, Franz B, Hess PR, et al. Podoplanin-rich stromal networks induce dendritic cell motility via activation of the C-type lectin receptor CLEC-2. Immunity (2012) 37:276-89. doi:10.1016/j.immuni.2012.05.022

124. Sakurai A, Doci CL, Gutkind JS. Semaphorin signaling in angiogenesis, lymphangiogenesis and cancer. Cell Res (2012) 22:23-32. doi:10.1038/cr.2011.198

125. Takamatsu H, Takegahara N, Nakagawa Y, Tomura M, Taniguchi M, Friedel $\mathrm{RH}$, et al. Semaphorins guide the entry of dendritic cells into the lymphatics by activating myosin II. Nat Immunol (2010) 11:594-600. doi:10.1038/ni.1885

126. Salmi M, Koskinen K, Henttinen T, Elima K, Jalkanen S. CLEVER-1 mediates lymphocyte transmigration through vascular and lymphatic endothelium. Blood (2004) 104:3849-57. doi:10.1182/blood-2004-01-0222

127. Karikoski M, Irjala H, Maksimow M, Miiluniemi M, Granfors K, Hernesniemi $\mathrm{S}$, et al. Clever-1/stabilin-1 regulates lymphocyte migration within lymphatics and leukocyte entrance to sites of inflammation. Eur J Immunol (2009) 39:3477-87. doi:10.1002/eji.200939896

128. Gazi U, Martinez-Pomares L. Influence of the mannose receptor in host immune responses. Immunobiology (2009) 214:554-61. doi:10.1016/j.imbio. 2008.11.004

129. Irjala H, Johansson EL, Grenman R, Alanen K, Salmi M, Jalkanen S. Mannose receptor is a novel ligand for $\mathrm{L}$-selectin and mediates lymphocyte binding to lymphatic endothelium. J Exp Med (2001) 194:1033-42. doi:10.1084/jem.194. 8.1033

130. Marttila-Ichihara F, Turja R, Miiluniemi M, Karikoski M, Maksimow M, Niemela J, et al. Macrophage mannose receptor on lymphatics controls cell trafficking. Blood (2008) 112:64-72. doi:10.1182/blood-2007-10-118984

131. Amatschek S, Kriehuber E, Bauer W, Reininger B, Meraner P, Wolpl A, et al. Blood and lymphatic endothelial cell-specific differentiation programs are stringently controlled by the tissue environment. Blood (2007) 109:4777-85. doi:10.1182/blood-2006-10-053280 
132. Norder M, Gutierrez MG, Zicari S, Cervi E, Caruso A, Guzman CA. Lymph node-derived lymphatic endothelial cells express functional costimulatory molecules and impair dendritic cell-induced allogenic T-cell proliferation. FASEB J (2012) 26:2835-46. doi:10.1096/fj.12-205278

133. Cohen JN, Guidi CJ, Tewalt EF, Qiao H, Rouhani SJ, Ruddell A, et al. Lymph node-resident lymphatic endothelial cells mediate peripheral tolerance via Aire-independent direct antigen presentation. J Exp Med (2010) 207:681-8. doi:10.1084/jem.20092465

134. Tewalt EF, Cohen JN, Rouhani SJ, Guidi CJ, Qiao H, Fahl SP, et al. Lymphatic endothelial cells induce tolerance via PD-L1 and lack of costimulation leading to high-level PD-1 expression on CD8 T cells. Blood (2012) 120:4772-82. doi:10.1182/blood-2012-04-427013

135. Melero I, Bach N, Chen L. Costimulation, tolerance and ignorance of cytolytic $\mathrm{T}$ lymphocytes in immune responses to tumor antigens. Life Sci (1997) 60:2035-41. doi:10.1016/S0024-3205(96)00686-8

136. Lund AW, Duraes FV, Hirosue S, Raghavan VR, Nembrini C, Thomas SN, et al. VEGF-C promotes immune tolerance in B16 melanomas and crosspresentation of tumor antigen by lymph node lymphatics. Cell Rep (2012) 1:191-9. doi:10.1016/j.celrep.2012.01.005

137. Tewalt EF, Cohen JN, Rouhani SJ, Engelhard VH. Lymphatic endothelial cells key players in regulation of tolerance and immunity. Front Immunol (2012) 3:305. doi:10.3389/fimmu.2012.00305

138. Sims TN, Dustin ML. The immunological synapse: integrins take the stage. Immunol Rev (2002) 186:100-17. doi:10.1034/j.1600-065X.2002.18610.x

139. Podgrabinska S, Kamalu O, Mayer L, Shimaoka M, Snoeck H, Randolph GJ, et al. Inflamed lymphatic endothelium suppresses dendritic cell maturation and function via Mac-1/ICAM-1-dependent mechanism. J Immunol (2009) 183:1767-79. doi:10.4049/jimmunol.0802167

140. Lippert U, Zachmann K, Ferrari DM, Schwarz H, Brunner E, Mahbub-Ul Latif $\mathrm{AH}$, et al. CD137 ligand reverse signaling has multiple functions in human dendritic cells during an adaptive immune response. Eur J Immunol (2008) 38:1024-32. doi:10.1002/eji.200737800

141. Palucka K, Banchereau J. Cancer immunotherapy via dendritic cells. Nat Rev Cancer (2012) 12:265-77. doi:10.1038/nrc3258

142. Lesterhuis WJ, De Vries IJ, Schreibelt G, Lambeck AJ, Aarntzen EH, Jacobs JF, et al. Route of administration modulates the induction of dendritic cell vaccine-induced antigen-specific $\mathrm{T}$ cells in advanced melanoma patients. Clin Cancer Res (2011) 17:5725-35. doi:10.1158/10780432.CCR-11-1261

143. De Vries IJ, Krooshoop DJ, Scharenborg NM, Lesterhuis WJ, Diepstra JH, Van Muijen GN, et al. Effective migration of antigen-pulsed dendritic cells to lymph nodes in melanoma patients is determined by their maturation state. Cancer Res (2003) 63:12-7.

144. de Vries IJ, Lesterhuis WJ, Barentsz JO, Verdijk P, Van Krieken JH, Boerman OC, et al. Magnetic resonance tracking of dendritic cells in melanoma patients for monitoring of cellular therapy. Nat Biotechnol (2005) 23:1407-13. doi:10.1038/nbt1154

145. Nair S, Mclaughlin C, Weizer A, Su Z, Boczkowski D, Dannull J, et al. Injection of immature dendritic cells into adjuvant-treated skin obviates the need for ex vivo maturation. J Immunol (2003) 171:6275-82.

146. Tripp CH, Ebner S, Ratzinger G, Romani N, Stoitzner P. Conditioning of the injection site with $\mathrm{CpG}$ enhances the migration of adoptively transferred dendritic cells and endogenous $\mathrm{CD}^{+}{ }^{+} \mathrm{T}$-cell responses. J Immunother (2010) 33:115-25. doi:10.1097/CJI.0b013e3181b8ef5f

147. Prins RM, Craft N, Bruhn KW, Khan-Farooqi H, Koya RC, Stripecke R, et al. The TLR-7 agonist, imiquimod, enhances dendritic cell survival and promotes tumor antigen-specific T cell priming: relation to central nervous system antitumor immunity. J Immunol (2006) 176:157-64.

148. Bracci L, La Sorsa V, Belardelli F, Proietti E. Type I interferons as vaccine adjuvants against infectious diseases and cancer. Expert Rev Vaccines (2008) 7:373-81. doi:10.1586/14760584.7.3.373

149. Cummings RJ, Gerber SA, Judge JL, Ryan JL, Pentland AP, Lord EM. Exposure to ionizing radiation induces the migration of cutaneous dendritic cells by a CCR7-dependent mechanism. J Immunol (2012) 189:4247-57. doi:10.4049/jimmunol.1201371

150. Chen X, Zeng Q, Wu MX. Improved efficacy of dendritic cell-based immunotherapy by cutaneous laser illumination. Clin Cancer Res (2012) 18:2240-9. doi:10.1158/1078-0432.CCR-11-2654

151. Alfaro C, Perez-Gracia JL, Suarez N, Rodriguez J, Fernandez De Sanmamed M, Sangro B, et al. Pilot clinical trial of type 1 dendritic cells loaded with autologous tumor lysates combined with GM-CSF, pegylated IFN, and cyclophosphamide for metastatic cancer patients. J Immunol (2011) 187:6130-42. doi:10.4049/jimmunol.1102209

152. Scandella E, Men Y, Gillessen S, Forster R, Groettrup M. Prostaglandin E2 is a key factor for CCR7 surface expression and migration of monocyte-derived dendritic cells. Blood (2002) 100:1354-61. doi:10.1182/blood-2001-11-0017

153. Kabashima K, Sakata D, Nagamachi M, Miyachi Y, Inaba K, Narumiya S. Prostaglandin E2-EP4 signaling initiates skin immune responses by promoting migration and maturation of Langerhans cells. Nat Med (2003) 9:744-9. doi:10.1038/nm872

154. Cueni LN, Detmar M. The lymphatic system in health and disease. Lymphat Res Biol (2008) 6:109-22. doi:10.1089/lrb.2008.1008

155. Kunstfeld R, Hirakawa S, Hong YK, Schacht V, Lange-Asschenfeldt B, Velasco P, et al. Induction of cutaneous delayed-type hypersensitivity reactions in VEGFA transgenic mice results in chronic skin inflammation associated with persistent lymphatic hyperplasia. Blood (2004) 104:1048-57. doi:10.1182/blood2003-08-2964

156. Zhang Q, Lu Y, Proulx ST, Guo R, Yao Z, Schwarz EM, et al. Increased lymphangiogenesis in joints of mice with inflammatory arthritis. Arthritis Res Ther (2007) 9:R118. doi:10.1186/ar2326

157. Yin N, Zhang N, Xu J, Shi Q, Ding Y, Bromberg JS. Targeting lymphangiogenesis after islet transplantation prolongs isletallograft survival. Transplantation (2011) 92:25-30. doi:10.1097/TP.0b013e31821d2661

158. Chen L, Hamrah P, Cursiefen C, Zhang Q, Pytowski B, Streilein JW, et al. Vascular endothelial growth factor receptor-3 mediates induction of corneal alloimmunity. Nat Med (2004) 10:813-5. doi:10.1038/nm1078

159. Nykanen AI, Sandelin H, Krebs R, Keranen MA, Tuuminen R, Karpanen T, et al. Targeting lymphatic vessel activation and CCL21 production by vascular endothelial growth factor receptor-3 inhibition has novel immunomodulatory and antiarteriosclerotic effects in cardiac allografts. Circulation (2010) 121:1413-22. doi:10.1161/CIRCULATIONAHA.109.910703

160. Sasaki M, Hasegawa H, Kohno M, Inoue A, Ito MR, Fujita S. Antagonist of secondary lymphoid-tissue chemokine (CCR ligand 21) prevents the development of chronic graft-versus-host disease in mice. J Immunol (2003) 170:588-96.

161. Cera MR, Fabbri M, Molendini C, Corada M, Orsenigo F, Rehberg M, et al. JAM-A promotes neutrophil chemotaxis by controlling integrin internalization and recycling. J Cell Sci (2009) 122:268-77. doi:10.1242/jcs.037127

Conflict of Interest Statement: Ignacio Melero has served as a consultant for Bristol Myers Squibb, Astra-Zeneca, Pfizer, Miltenyi Biotec, and Merk-Serono. The other co-authors declare that the research was conducted in the absence of any commercial or financial relationships that could be construed as a potential conflict of interest.

Received: 23 October 2013; paper pending published: 12 November 2013; accepted: 21 November 2013; published online: 09 December 2013.

Citation: Teijeira A, Rouzaut A and Melero I (2013) Initial afferent lymphatic vessels controlling outbound leukocyte traffic from skin to lymph nodes. Front. Immunol. 4:433. doi: 10.3389/fimmu.2013.00433

This article was submitted to Tumor Immunity, a section of the journal Frontiers in Immunology.

Copyright (C) 2013 Teijeira, Rouzaut and Melero. This is an open-access article distributed under the terms of the Creative Commons Attribution License (CC BY). The use, distribution or reproduction in other forums is permitted, provided the original author(s) or licensor are credited and that the original publication in this journal is cited, in accordance with accepted academic practice. No use, distribution or reproduction is permitted which does not comply with these terms. 